\title{
Assessment of Coriandrum Sativum L., Trigonella Foenum Graecum L., Pimpinella Anisum L., and Their Combinations Effect on Growth Performance, Carcass Trait and Hematobiochemical Parameters in Broiler Chicken
}

\section{MERADI Samira}

Universite Mohamed Khider de Biskra

Ahmed MESSAï ( $\nabla$ ahmed.messai@univ-biskra.dz )

Universite Mohamed Khider de Biskra https://orcid.org/0000-0002-1509-5319

Research Article

Keywords: Broilers, Natural alternatives, Performances, Blood Parameters, Phytogenics

Posted Date: January 25th, 2022

DOI: https://doi.org/10.21203/rs.3.rs-1247372/v1

License: (c) (1) This work is licensed under a Creative Commons Attribution 4.0 International License.

Read Full License 


\section{Abstract}

This study has been designed to examine the effects of three phytogenic feed additives (PHT) on certain zootechnical and hematobiochemical parameters in broiler chicken. The PHT were formulated from Coriandrum sativum L., Trigonella foenum-graecum L., and Pimpinella anisum L. 360 one-day-old Cobb broilers were randomly divided into 4 dietary treatment groups; a control group (CTLG), and three groups fed a basal diet supplemented respectively with $3 \%$ of Coriander (PHT1G), $3 \%$ of a combination $50 \%$ Coriander- $50 \%$ Fenugreek (PHT2G), and finally $3 \%$ of a combination $50 \%$ Coriander- $50 \%$ Anise (PHT3G). The results showed that the birds of PHT3 group realized the highest live body and internal organs weight. However, the weight of the abdominal fat was not affected. Broilers in the same group had a significantly $(\mathrm{P}<0.05)$ higher lymphocyte level $120.10^{3} / \mu \mathrm{l}$, followed by $\mathrm{PHT} 2$ group with $80.10^{3} / \mu \mathrm{l}$. The level of monocytes in PHT2 and PHT3 groups was respectively $66.10^{3} / \mu \mathrm{l}$ and $60.10^{3} / \mu \mathrm{l}$. Concerning the granulocytes, we noted $200.10^{3} / \mu \mathrm{l}$ in PHT2 group and $102.10^{3} / \mu \mathrm{l}$ in PHT3G. A significant difference (P $<0.05$ ) was recorded in the uric acid levels with $50.4 \mathrm{mg} / \mathrm{l}, 59.84 \mathrm{mg} / \mathrm{l}$, and $47.29 \mathrm{mg} / \mathrm{l}$ respectively for PHT1G, PHT2G, and PHT3G groups. Levels of the uric acid were lower than the level recorded in the control group $(84.36 \mathrm{mg} / \mathrm{l})$. The use of the phytogenic feed additives we formulated may have a positive effect both on weight gain and hematobiochemical parameters in broiler chicken, especially the levels of different types of white blood cells, and the uric acid rate.

\section{Introduction}

The utilization of herbs and spices was extensively studied in poultry diets as an alternative to antibiotics, and as growth promoters (Abd El-Hack et al., 2021; Kuralkar and Kuralkar, 2021; Paula et al., 2020). Feeding medicinal herbs to poultry is beneficial to respond to the consumer's needs and legislative limitations about avoiding the utilization of antibiotic growth promoters and ionophores in modern intensive poultry production (Adhikari et al., 2019). Consumers have interested in meat quality, which is produced through sustainable livestock products that are free of chemicals which harmful to health, and simultaneously have superior sensorial and preservation characteristics (Socaci et al., 2020). The effets of phytogenics are linked to their specific phytochemical components. The bioactive molecules improve chicken potential production, through enhancing poultry immunity (Oladokun and Adewole, 2020; Rasouli et al., 2019) and improving the digestive process. They preserve the balanced gut microflora and intestinal uptake (Kim et al., 2019), and reduce the disease spreading. These advantages can be achieved by including various medicinal plants in the feed or drinking water of broiler breeding (Seidavi et al., 2021). Another advantage of incorporating additives is to enrich the food with antioxidants and bioactif antimicrobial compounds (Hashemi et al., 2012). Among many spices, coriander is a medicinal and spice plant, that leaves, seeds, and fruits have many beneficial biological characteristics, such as antimicrobial, antioxidant, and anti-inflammatory activities (Silva et al., 2020; Socaci et al., 2020). Considerable researches outline that the coriander seed in poultry feed has a positive impact on improving zootechnical performance, carcass yield, blood biochemical profile, and mineral composition of chicken meat (Khubeiz and Shirif, 2020; Jameel, 2019). Hosseinzadeh et al. (2014) reported that the coriander 
seed powder has been used as an alternative to antibiotics against Newcastle and infectious bronchitis in the chicken feed.

Fenugreek is rich in flavonoids, phenols, saponins, alkaloids, and other bioactive compounds (Akbari et al., 2020). It has many have interesting bioactivity characteristics such as antimicrobial, antioxidation, antifungal, antiviral properties, digestive stimulation, and immunomodulation (Srinivasa and Naidu, 2020). Recent studies in broiler chickens have shown that the supplementation of fenugreek reduces significantly blood cholesterol and Glycemia levels, promotes immune response, improved plasma total protein, and globulin (Al-Homidan et al., 2020; Wahab et al., 2019).

Furthermore, Green Anise has an antimicrobial property. With its active components improve the biochemical profile of blood, increase the levels of calcium and phosphorus in serum, and improve the Albumin/Globulin ratio which promotes the resistance of chickens againstdifferent stress factors (Charal et al., 2017). Gupta et al. (2021), and Hemati et al. (2019), reported that the Green Anise increases immune response, improves meat quality, ameliorates the gut bacteria, and morphological characteristics.

Either individually or as a combined mixture, phytogenic herbs and species preserve broiler's safety and production (Hafeez et al., 2020; Meradi et al., 2020). Studies on the use of phytogenics as growth promoters in animal production are numerous, but the virtues of these natural products are still worth exploring. In this context, the present study aimed to assess the effects of Coriandrum sativum $\mathrm{L}$. and its combination with Pimpinella anisum L., and Trigonella foenum graecum L. on growth performance, carcass trait, and hematobiochemical parameters in broiler chickens.

\section{Material And Methods}

\section{Animals and diets}

A total of 360 one-day-old, Cobb 500 broilers (non sexed) were purchased from a commercial hatchery, and raised in litter floor pens at the department of Agricultural sciences. University of Biskra. Algeria. The chicks had an initial body weight of $47.33 \pm 0.10 \mathrm{~g}$.

4 dietary treatment groups were formed: a control group fed a basal diet (CTLG), and three groups fed a basal diet supplemented with a Phytogenic formulation. A group with $3 \%$ of Coriander supplementation (PHT1G), a group with $3 \%$ of a combination $50 \%$ Coriander-50\% Fenugreek (PHT2G), and finally a group with $3 \%$ of a combination $50 \%$ Coriander-50\% Anise (PHT3G). Each experimental group contain 3 repetitions of 30 birds.

Feed and water were given ad libitum. The rations were formulated to be isocaloric and isonitrogenous according to NRC (1994) recommandations. In the table 1 the ingredients and nutrient compositions of basal diet are summarized. 
Table 1: Ingredients and nutrient compositions of basal diet.

\begin{tabular}{|lll|}
\hline & Starter(0-15d) & Grower (16-42d) \\
\hline Ingredients & & \\
\hline Maize & 63 & 65 \\
Soybean meal & 29 & 27 \\
Wheat Bran & 5 & 5 \\
Phosphate & 1 & 1 \\
Calcaire & 1 & 1 \\
CMV & 1 & 1 \\
\hline Chemical composition & & \\
\hline EM(Kcal/kg) & 3820.57 & 3844.97 \\
DM \% & 92.73 & 92.65 \\
Crude Proteins (\%DM) & 22.06 & 20.75 \\
Ether extract(\%DM) & 2.06 & 2.08 \\
Ash (\%DM) & 5.02 & 4.52 \\
Fibre (\%DM) & 4.33 & 4.02 \\
Calcium (\%DM) & 6.97 & 1.31 \\
P disponible & 0.69 & 0.63 \\
Lysine (\%CP) & 3.23 & 3.55 \\
Méthionine (\%CP) & 1.34 & 1.44 \\
\hline
\end{tabular}

DM: Dry Matter, CP Crude Proteins.

\section{Plant material}

In our study, the three plants tested were used as a seeds. Within 6 days after collection, seeds were cleaned, air-dried and stored under correct conditions until used as phytogenics. The harvest of the three types of seeds (Coriandrum sativum L., Trigonella foenum graecum L., and Pimpinella anisum L.) was carried out during 2020 at Biskra province in Algeria.

Voucher specimens were deposited at the Scientific and Technical Research Centre on Arid regions (CRSTRA) under the numbers: (003CRSTRA0003) for Coriandrum sativum L., (011CRSTRA0006) for Trigonella foenum graecum L., and (003CRSTRA0011) for Pimpinella anisum L. 


\section{Growth Performances and Carcass Trait}

Zootechnical parameters were measured. Regularly, diets distributed and feed refused were weighted to determine the feed intake and the feed conversion ratio. However, weekly birds were weighed to calculate the average daily weight gain. At the end of the experiment period (day 42), ten subjects per replicate were randomly taken from each group, and individually weighed to determine live body weight. The selected birds were sacrificed, eviscerated. The carcasses and the internal organs: liver, proventriculus, gizzard, small intestine were weighted. The abdominal fat, the breast, and the leg (thigh+drumstick) were measured. The carcass yield was expressed as a percentage of live body weight.

\section{Hematobiochemical parameters}

At the39th day, ten subjects were randomly chosen from each group. The blood samples were collected from the wing vain. Blood biochemistry (Glycemia, Total cholesterol, Total Proteins, Uric acid, Creatinine level, Globulin, and Albumin levels) were tested. An assessment of the blood cellular composition (Red Blood Cell, lymphocytes, monocytes, and granulocytes) was performed.

\section{Statistical analysis}

Using SPSS, Data obtained on various parameters were statistically analyzed by analysis of variance (ANOVA) followed by a comparison of means, according to the Newman and Keuls tests. The difference was considered significant when $p<0.05$.

\section{Results}

\section{Growth Performances}

The analysis of the results shows that during 42days, the best live body weight and the highest average daily gain (ADG) were recorded in PHT3G with 2966.98g and 70.64g successively. However, the feed intake did not affect $(P<0.05)$ among PHTG3, PHTG2, and the CTLG, which are successively $4206.65 \mathrm{~g}$, $4187.06 \mathrm{~g}$, and $4083.44 \mathrm{~g}$. The best feed conversion ratio (FCR) was recorded without significant difference $(p<0.05)$ in the CTLG the PHTG2, and the PHTG3 which are $(1.40 ; 1.46$ and 1.47$)$ consecutively. Results are presented in the table 2.

Table 2. Growth performances in experimental groups. 


\begin{tabular}{|c|c|c|c|c|c|}
\hline & CTLG & PHT1G & PHT2G & PHT3G & ESM \\
\hline \multirow[b]{2}{*}{$\begin{array}{l}\text { LBW } \\
\text { (g/bird) }\end{array}$} & \multicolumn{2}{|l|}{$2945.02^{(b)} \pm 13.2$} & $2927.62^{(\mathrm{a})} \pm 148.89$ & $2966.98^{(\mathrm{c})} \pm 37.38$ & \multirow[b]{2}{*}{2.31} \\
\hline & $70.12^{(a)} \pm 0,31$ & $2919.58^{(a)} \pm 92.88$ & $69.71^{(\mathrm{a})} \pm 3,54$ & $70.64^{(\mathrm{a})} \pm 0.89$ & \\
\hline ADG (g) & \multirow{3}{*}{$\begin{array}{l}4083,44^{(a)} \\
\pm 4,32 \\
1.38^{(a)} \pm 0,007\end{array}$} & $69.51^{(\mathrm{a})} \pm 2,21$ & $4187,06^{(a)} \pm 125,47$ & $\begin{array}{l}4206,65^{(a)} \\
+9384\end{array}$ & \multirow{3}{*}{$\begin{array}{l}1.252 \\
0.019\end{array}$} \\
\hline $\begin{array}{l}\text { Feed } \\
\text { intake } \\
\text { (g/bird) }\end{array}$ & & \multirow{2}{*}{$\begin{array}{l}4859,95^{(b)} \\
\pm 92,69 \\
1.67^{(b)} \pm 0,04\end{array}$} & \multirow[t]{2}{*}{$1.43^{(\mathrm{a})} \pm 0.03$} & \multirow[t]{2}{*}{$1.42^{(a)} \pm 0.04$} & \\
\hline FCR & & & & & \\
\hline $\begin{array}{l}\text { LBW: Liv } \\
\text { a,b,c,d Mea } \\
\text { dietary. }\end{array}$ & $\begin{array}{l}\text { dy weight; } A D G \text { : } \\
\text { in the same row }\end{array}$ & erage daily gain ; $F$ & $\begin{array}{l}\text { R: Feed conversion R } \\
\text { W significant differe }\end{array}$ & $\begin{array}{l}\text { tio. } \\
\text { ces }(p<0.05) \text { amons }\end{array}$ & \\
\hline
\end{tabular}

\section{Carcass Trait}

The analysis of the statistical data summarized in table 3, shows birds have fed PHTG3 and those in the CTLG have realized the higher live body weight and eviscerated carcass. However, the highest carcass yield $75.44 \%$ was obtained with PHTG2, followed by PHTG3 with $73.16 \%$. Indeed, the percentage of the breast was improved by PHTG1 and PHTG2 with $31.70 \%$ and $31.22 \%$ respectively. The percentage of the leg has improved with PHTG3 with 9.73\% more than those on the other experimental diet. The abdominal fat did not affect by the phytobiotc compounds PHTG2 and PHTG3. Whereas, we noted the Weight of different visceral organs improved significantly $(p<0.05)$ with PHTG3. The carcass components are summarized in table 3.

Table 3. Carcass components. 


\begin{tabular}{|c|c|c|c|c|c|}
\hline & CTLG & PHT1G & PHT2G & PHT3G & ESM \\
\hline $\begin{array}{l}\text { LBW at slaughter } \\
\text { (g) }\end{array}$ & $\begin{array}{l}3325(b) \pm \\
240,42\end{array}$ & $\begin{array}{l}3217,50(\mathrm{~b}) \\
\pm 357.09\end{array}$ & $\begin{array}{l}2810(a) \\
\pm 28.28\end{array}$ & $\begin{array}{l}3290(\mathrm{~b}) \\
\pm 275.77\end{array}$ & \multirow{2}{*}{$\begin{array}{l}0.198 \\
0.198\end{array}$} \\
\hline $\begin{array}{l}\text { Eviscerated } \\
\text { carcass (g) }\end{array}$ & $\begin{array}{l}2405(\mathrm{~b}) \\
\pm 197.99\end{array}$ & $\begin{array}{l}2315(\mathrm{~b}) \\
\pm .296 .98\end{array}$ & $\begin{array}{l}2120(\mathrm{a}) \\
\pm 70.71\end{array}$ & $\begin{array}{l}2407.5(\mathrm{~b}) \\
\pm 208.60\end{array}$ & \\
\hline Carcass yield (\%) & 72,33 & 71,96 & 75,44 & 73,16 & \multirow[t]{2}{*}{0.300} \\
\hline Breast(g) & $\begin{array}{l}987(\mathrm{~b}) \\
\pm 102.53\end{array}$ & $1020(c) \pm 28.28$ & $\begin{array}{l}877.5(a) \\
\pm 17.68\end{array}$ & $930(b) \pm 183.85$ & \\
\hline Breast(\%) & 29.68 & 31.70 & 31.22 & 28.27 & \multirow[t]{2}{*}{0.525} \\
\hline Leg $(g)$ & $310(b) \pm 21.21$ & $305(b) \pm 14.14$ & 255(a) & $320(b) \pm 49.50$ & \\
\hline $\begin{array}{l}\text { Leg }(\%) \\
\text { Abdominal fat(g) }\end{array}$ & 9.32 & $\begin{array}{l}9.48 \\
51^{(b)} \pm 1.41\end{array}$ & $\begin{array}{l} \pm 14.14 \\
9.07\end{array}$ & $\begin{array}{l}9.73 \\
40^{(a, b)} \pm 8.49\end{array}$ & 0.112 \\
\hline Abdominal fat (\%) & $27^{(\mathrm{a})} \pm 4.24$ & 1.59 & $33^{(a)} \pm 7.07$ & 1.21 & \multirow[t]{2}{*}{0.300} \\
\hline Heart(g) & $1 \mathrm{a}^{(\mathrm{a})}+1$ & $14.06^{(\mathrm{a})} \pm 1.41$ & 1.17 & $17^{(\mathrm{a})} \pm 2.83$ & \\
\hline Heart(\%) & $14^{(\mathrm{d})} \pm 1.41$ & 0.44 & $15^{(\mathrm{a})} \pm 1.44$ & 0.51 & 0.252 \\
\hline Liver(g) & $50(a)+707$ & $78^{(b)} \pm 26.87$ & 0.53 & $66.5^{(a, b)} \pm 9.19$ & \multirow{2}{*}{0.537} \\
\hline $\begin{array}{l}\text { Liver(\%) } \\
\text { Proventriculus(g) }\end{array}$ & $\begin{array}{l}59(0) \pm 1.07 \\
1.77\end{array}$ & 2.42 & $52^{(a)} \pm 7.07$ & 2.02 & \\
\hline Proventriculus(\%) & $9^{(b)} \pm 0.01$ & $10^{(\mathrm{b})} \pm 2.83$ & 1.85 & $9.05^{(b)} \pm 0.03$ & \multirow[t]{4}{*}{0.139} \\
\hline Gizzard(g) & 0.27 & 0.31 & $7.5^{(\mathrm{a})} \pm 0.71$ & 0.27 & \\
\hline Gizzard(\%) & $47.5^{(\mathrm{a})} \pm 20.51$ & $56^{(b)} \pm 9.90$ & 0.27 & $50^{(a, b)} \pm 2.83$ & \\
\hline & 1.43 & 1.74 & $\begin{array}{l}46^{(\mathrm{a})} \pm 5.66 \\
1.64\end{array}$ & 1.51 & \\
\hline
\end{tabular}

\section{Hematobiochemical Parameters}

Glycemia values of all groups have not affected by the phytobiotics compounds $(P<0.05)$. However, the total cholesterol were significantly lower in PHT G 1, PHTG2, and PHTG3 groups than the CTLG $(P<0.05)$, the cholesterol levels were $0.92 \mathrm{~g} / \mathrm{l} ; 0.95 \mathrm{~g} / \mathrm{l}$ and $1.05 \mathrm{~g} / \mathrm{l}$ for PHTG3, PHTG1, and PHTG2 successively. 
The values of total protein with PHTG1, PHTG2 were highest than the control and PHTG3 $(P<0.005)$, both coriander and PHTG2 caused an increase in plasma protein levels. Concerning globulin, we have recorded the highest value in PHTG1 and PHTG2 but without significant difference $(P<0.05)$. The highest value of Albumin was recorded with PHTG2 followed by PHTG1 $(12.19 \mathrm{~g} / \mathrm{l}, 11.41 \mathrm{~g} / \mathrm{l}$ and $10.81 \mathrm{~g} / \mathrm{l})$ successively. Regarding the ratio (Albumin/Globulin), the most important value was recorded in PHTG3with 0.86 and in the CTLG with 0.76 . The lowest ratio was recorded in PHTG1 and PHTG2 successively ( 0.37 and 0.43 ). We have noted a significant difference in the uric acid levels $(P<0.05)$, the lower values were registered in experimental groups $50.4 \mathrm{mg} / \mathrm{l}, 59.84 \mathrm{mg} / \mathrm{l}$, and $47.29 \mathrm{mg} / \mathrm{l}$ respectively in PHTG1, PHTG2, and PHTG3. In fact, we were recorded the lower value of red blood cells $3.48 .10^{6} / \mathrm{mm}^{3}$ in the CTLG and the highest lymphocyte level with PHTG3 group which is $120.10^{3} / \mu$, followed by PHTG2 with $80.10^{3} / \mu \mathrm{l}$. The important level of monocytes was noted with PHTG2 and PHTG3 successively $66.10^{3} / \mu \mathrm{l}, 60.10^{3} / \mu \mathrm{l}$. Involving the granulocytes, we noted $200.10^{3} / \mu \mathrm{l}$ for PHTG2 and $102.10^{3} / \mu \mathrm{l}$ for PHTG3. The Hematobiochemical results are summarized in table 4.

Table 4. Hematobiochemical Parameters

\begin{tabular}{|c|c|c|c|c|c|}
\hline & CTLG & PHT1G & PHT2G & PHT3G & ESM \\
\hline \multicolumn{6}{|l|}{ Blood biochemistry } \\
\hline Glycemia (g/l) & $2,21(a)$ & $2,09(a)$ & $2,58(a)$ & $2,37(a)$ & 0.622 \\
\hline Total cholesterol (g/l) & 1,19(a) & $0,95(a)$ & $1,05(a)$ & $0,92(a)$ & 0.431 \\
\hline Total protein $(\mathrm{g} / \mathrm{l})$ & $26,25(a)$ & $39,37(b)$ & $40,48(b)$ & $20,5(a)$ & 0.655 \\
\hline uric acid (Uricemie)(mg/l) & $84,36(c)$ & $50,4(a)$ & $59,84(b)$ & $47,29(a)$ & 0.623 \\
\hline Creatinine level (mg/l) & $2,3(a)$ & $2,7(a)$ & $2,2(a)$ & $2,2(a)$ & 0.222 \\
\hline Globulin (g/l) & $14,84(a)$ & $28,56(b)$ & $28,29(b)$ & $10,97(a)$ & 0.516 \\
\hline Albumin level (g/l) & $11,41(a)$ & $10,81(a)$ & $12,19(b)$ & $9,53(a)$ & 0.122 \\
\hline Albumin/ Globulin & $0,76(b)$ & $0,37(a)$ & $0,43(a)$ & $0,86(b)$ & \\
\hline \multicolumn{6}{|l|}{ Hematology } \\
\hline Red blood cell /mm3 & $3,48.106(a)$ & $4,08.106(a)$ & $3,95.106(a)$ & $3,82.106(a)$ & 0.687 \\
\hline Lymphocytes / $\mu \mathrm{l}$ & $62.103(a)$ & $60.103(a)$ & 80.103(b) & 120.103(c) & 0.852 \\
\hline Monocytes / $\mu$ l & $12.103(a)$ & 18.103(a) & 66.103(b) & $60.103(b)$ & 0.866 \\
\hline Granulocytes / $\mu \mathrm{l}$ & 66.103(a) & 72.103(a) & 200.103(c) & 102.103(b) & 0.874 \\
\hline
\end{tabular}




\section{Discussion}

\section{Growth Performance}

Our Growth Performance results are in agreement with results obtained by (Samani et al., 2020; Barad et al., 2016; Kirubakaran et al., 2016; Sunbul et al., 2010). Authors confirmed the improvement of live body weight, feed intake and decrease the FCR of broiler chicken by supplementation of coriander seeds, fenugreek, and green anise. Moreover, the biological effects depend on the doses and the ratios between the different natural products used (Alleman et al., 2013; Lee et al., 2003). Phytogenic feed additives improve feed palatability. Herbs, spices, and their active compounds have positive outcome as food condiments through the oronasal system. Oronasal sensing induces the gastrointestinal tract to receive food and stimulates digestive secretions (Brenes and Roura, 2010). Also, in vitro analysis confirmed the increasing of activities of pancreatic lipase and amylase when the diet is mixed with various spices and spice extracts. According to Lillehoj et al. (2018), there is a significant relationship between specific bacterial populations and some phytochemicals in the gut of domestic animals which induces to a better productivity. Natural compounds are able to modulate the gastrointestinal microbiota and increase animal welfare and production. Gut is a very important organ, because it has both functions of digestion and host immunity (Sugiharto, 2016). According to Abd El-Hack (2021), and Qureshi (2020), dandelion leaves and fenugreek seeds have beneficial effects on intestinal morphology. Histological examination showed improvement of jejunal villus height, ratio between villus height and crypt depth, and less infiltration of mononuclear cell, which helps to improve the absorptive surface for better nutrient utilization. On the other hand, Khubeiz and Shirif (2020), Barreto et al. (2008), have reported the insignificant effects of phytogenic seed as feed additive powder in the diet at different levels on bird performance. Lee et al. (2003) explained this effect by the high nutrition quality of the basal diet and the environmental conditions ; diets containing highly digestible ingredients limit the proliferation of bacteria in the intestinal tract as there is no substrate to support bacterial growth.

In our study, the improvement of the growth performance with the phytogenic feed additive composed by coriander and green anise can be due to the enhancing of palatability and digestive enzymes, which are affected by the level of linalool (Brenes and Roura, 2010). Therefore, the antibacterial characterization of the spices against the development of damaging microflora, which they act as phytogenic growth promoters (Pathak et al., 2011).

\section{Carcass Trait}

Results about the effect of phytobiotics on carcass and internal organ performance are in agreement with the results of several researchers, who have reported that natural products improve feed intake and live weight of birds, which affects carcass yield, liver, heart, and gut (Alçiçek et al., 2003; Giannenas et al., 2003). In the review research of Silva et al. (2020), they reported that the coriander seeds in chicken's diet improve weight gain and carcass yield. Similarly, authors showed that supplementation with coriander seeds or coriander essential oil could improve broiler intestinal health and provide an important contribution to the health status of the animals. Al-Homidan et al. (2020), Awadein et al. (2010), have 
noted that incorporation of fenugreek in the diet has no negative effect on performance, carcass and internal organ weights of chicken. In fact, herbs and spices bioactive compounds have beneficial effects on animal welfare and enhance meat nutritional quality. Several strategies have been adopted to enrich animal products, especially the fatty acid profile of meat by introducing plants into their diet by enriching them with Omega3 (Mourot, 2009). Phytobiotics promote digestion which can influence weight gain, because it involved regulation and modulation of the metabolic and immune system (Gadde et al., 2017). Actually, much research focused on meat quality and the oxidation process. Lipid and protein oxidation is recognized as a major threat to the quality of poultry products. The implication of phytochemicals in the feed or directly in the meat product is a significant solution (Akram et al., 2020).

In our study the significant improvement of carcass parameters could be explained by the stimulatory effects of digestive enzymes secretions, which induce to better absorption of nutrients, such as amino acids, from the digestive tract (Rahimi et al., 2011). Furthermore, the antioxidants compound and phenolic substance in vegetables products improved the carcass breast of broiler by $1.2 \%$ (Abo Omar et al., 2016).

\section{Hematobiochemical Parameters}

Our hematobiochemical parameters results are in agreement with those obtained by Saeid and Al Nasry (2010), who noted tha the Glycemia level varied between $(1,09 \mathrm{~g} / \mathrm{l}-2,13 \mathrm{~g} / \mathrm{l})$ with different incorporating levels of coriander seeds in broiler's feed. Chettouh and Riabi (2019), Adil (2015), Mamoun et al. 2014 and Safaei et al. (2013), reported that incorporation of fenugreek seeds reduced blood cholesterol and Glycemia levels in broilers. Our result about the reduction in serum cholesterol may be due to the presence of saponins and resins in fenugreek, which inhibits the absorption of bile acids and cholesterol in the gut, leading to a reduction in blood cholesterol levels (Petit et al, 1995). Brenes and Roura (2010) have reported improving pancreatic digestive enzymes with incorporation of phytogenic compounds in poultry feed. According to Oueslati and Ghédira (2015) numerous pharmacological and clinical studies have shown that fenugreek has antioxidant, cholesterol-lowering, and hypoglycemic effects due to the effects of the constituents of the seed including steroids (diosgenin), alkaloids (trigonelline), flavonoids (luteolin), coumarins, amino acids (hydroxy isoleucine), mucilages (galactomannan), volatile constituents, fixed oil, and various other substances. The determination of these molecules is used to assess physiologic functions, immune system and to monitor metabolic and nutritional diseases (Lee et al., 2010). Our results agree with those reported by Mamoun et al. (2014), and Saeid and Al Nasry (2010), who noted that the level of uricemia decreased with the incorporation of fenugreek and coriander. AlShammari et al. (2017) showed that the addition of anise seed powder in the drinking water of Hubbard Classic broilers improves significantly the blood profile; anise seed can be considered as an effective physiological promoter in broilers. Adil et al. (2015) have mentioned a significant improvement in red blood cell volume and Hemoglobulin concentration with adding $10 \mathrm{~g} / \mathrm{kg}$ of fenugreek in broiler's diet ( $\mathrm{p}<$ 0.05). However, others noted, unlike by the incorporation of fenugreek the serum metabolites and immune responses of laying hens were not impacted (Samani et al., 2020). Saeid and Al Nasry (2010) confirmed 
that coriander seeds improve the hematological composition of red blood cells, hemoglobin, and plakets, while he found no difference in white blood cells in broiler chickens.

\section{Conclusion}

The effect of phytobiotic compound PHTG2 and PHTG3 are more importance than the effect of coriander used alone. However, indeed PHTG3 was the most interesting formulation, followed by PHTG2. Live body weight, Average Daily Gain, feed intake, FCR, and carcass yield have been improved. The percentage of the breast and the leg were enhanced. In fact, the abdominal fat was not affected by the phytobiotic compounds. The PHTG3 affectes positively the weight of the liver, proventriculus and gizzard. The association of Coriandrum sativum L. with Pimpinella anisum L. and Trigonella foenum graecum $\mathrm{L}$. have a positive effect on hematobiochemical parameters in broiler chicken especially increasing the level of different types of white blood cells (lymphocyte, monocytes, and granulocytes). Further, the incorporation of these natural products reduced the total cholesterol, increase plasma protein levels. The ratio (Albumin / Globulin) was affected strongly. The uric acid levels were decreased significantly.

\section{Declarations}

\section{Acknowledgments}

We would like to thank gratefully the support and cooperation of Salem Poultry Complex in Algeria, Debabech Chelghoum Nour El Houda Laboratory MDALAB and Mr. Khachaï Salim the head of the department of Agricultural sciences. University of Biskra. Algeria.

Funding: This study was partially funded by the DGRSDT and the Ministry of Higher Education and Scientific Research of Algeria for PRFU Project (D04N01UN070120190002).

\section{Conflicts of interest/Competing interests:}

The authors declare that they have no conflict of interest.

Availability of data and material: Not applicable for this study.

Code availability: Not applicable for this study.

\section{Authors' contributions}

All authors contributed to the study conception and design. The original draft conception and its revising were performed by MERADI Samira (a doctoral student). Reviewing the paper and analyzing data were performed by MESSAÏ Ahmed. All authors read and approved the final manuscript.

\section{Ethics approval}


This study followed the international guidelines of animal care and use in research and teaching (NRC, 2011). All procedures performed in this research were approved in the Scientific and Technical Research Centre on Arid regions (CRSTRA)-University of Biskra.

Consent to participate: Not applicable for this study.

Consent for publication: Not applicable for this study.

\section{References}

1. Abd El-Hack, M.E., El-Saadony, M.T., Saad, AM., Salem, H.M., Ashry, NM., Abo Ghanima, M. M., Shukry, M., Swelum, A. A., Taha, A.E., El-Tahan, A.M., AbuQamar, S.F., El-Tarabily, Kh. A., 2021. Essential oils and their nanoemulsions as green alternatives to antibiotics in poultry nutrition: a review, Poultry Science, 101584, https://doi.org/10.1016/j.psj.2021.101584

2. Abo Omar, J., Hejazi, A. and Badran, R. 2016. Performance of broilers supplemented with natural herb extract. Open Journal of Animal Sciences. 6, 68-74. https://doi.org/10.4236/ojas.2016.61009

3. Adhikari, P., Kiess, A., Adhikari, R., Jha, R., 2019. An approach to alternative strategies to control avian coccidiosis and necrotic enteritis, Journal of Applied Poultry Research, 29, 515-534, https://doi.org/10.1016/j.japr.2019.11.005

4. Adil, S., Qureshi, S., Pattoo, R A., 2015. A Review on Positive Effects of Fenugreek as Feed Additive in Poultry Production, International Journal of Poultry Science, 14(12), 664669, https://doi.org/10.3923/ijps.2015.664.669

5. Akbari, S., Abdurahmana, N. H., Fayaz, F., Noory, V., 2020. Iridoids of fenugreek (Trigonella-foenumgraecum L.) seed extract detected via LC-QTOF-MS analysis, Future Foods 4, 100067, https://doi.org/10.1016/j.fufo.2021.100067

6. Akram, R., Iqbal, R., Hussain, R., Ali, M., 2020. Effects of bisphenol a on hematological, serum biochemical, and histopathological biomarkers in bighead carp (Aristichthys nobilis) under long-term exposure, Environmental Science and Pollution Research, https://doi.org/10.1007/s11356-02117329-1

7. Alçiçek, A., Bozkurt, M.,Cabuk, M., 2003. The effect of an essential oil combination derived from selected herbs growing wild in Turkey on broiler performance, South African Journal Of Animal Science, 33, 2, 89-94, https://doi.org/10.4314/sajas.v33i2.3761

8. Al-Homidan, I.H., Ebeid, T.A., Al-Muzaini, A., Abou-Emera, O.K., Mostafa, M.M., Fathi, M. M., 2020. Impact of dietary fenugreek, mung bean, and garden cress on growth performance, carcass traits, blood measurements, and immune response in broiler chickens, Livestock Science, 242,104318, https://doi.org/10.1016/j.livsci.2020.104318

9. Alleman, F., Gabriel, I., Dufourcq, V., Perrin, F., Gabarrou, J.F., 2013. Utilisation des huiles essentielles en alimentation des volailles. 1. Performances de croissance et réglementation, INRA Production Animal, 26, 1, 3-12, https://doi.org/10.20870/productions animales.2013.26.1.3130 
10. Al-Shammari, K I A., Batkowska, J., Gryzińska, MM., 2017 Effect of Various Concentrations of an Anise Seed Powder (Pimpinella anisum L.) Supplement on Selected Hematological and Biochemical Parameters of Broiler Chickens. Brazilian Journal of Poultry Science.19, 41-46, https://doi.org/10.1590/1806-9061-2016-0331

11. Awadein, N.B., Eid, Y.Z., El-Ghany, FAA., 2010. Effect of dietary supplementation with phytoestrogens sources before sexual maturity on productive performance of mandarah hens. Egypt, Poultry Science, 30, 3, 829-846, https://www.researchgate.net/publication/215784624

12. Barad, N.A., Savsani, H.H., Patil, S.S., Garg, D.D., Oliva, Das.,Singh, V., Kalaria, V.A., Chatrabhuji, B.B., 2016. Effect of feeding coriander seeds, black pepper and turmeric powder as feed additives on hematobiochemical profile and performance of broiler chicken. International Journal of Science, Environment and Technology, 5, 6, 3976 - 3982, https://www.ijset.net/journal/1406.pdf

13. Barreto, M.S.R., Menten, J.F.M., Racanicci, A.M.C., Rizzo, P.V., 2008. Plant extracts used as growth promoters in broilers, Brazilian Journal of Poultry Science, 10, 109-

115, https://doi.org/10.1590/S1516-635X2008000200006

14. Brenes, A., Roura, E., 2010. Essential oils in poultry nutrition: Main effects and modes of action, Animal Feed Science and Technology, 158, 1-14, https://doi.org/10.1016/j.anifeedsci.2010.03.007

15. Charal, J. W., Bidner, T. D., Southern, L. L., Janes, M. E., Gutierrez, M. E., Lavergne. T. A., 2017. Anise oil dosage and its effect on growth performance and jejunal lesions during a Clostridium perfringens challenge in battery trials, and growth performance in a floor pen trial, Journal of Applied Poultry Research, 26, 240-252, http://dx.doi.org/10.3382/japr/pfw068

16. Chettouh, A., Riabi, S., 2019. Etude de quelques paramètres hématologiques et morphométriques chez le poulet de chair (Gallus gallus domesticus) face à une perturbation du régime alimentaire en région d'Ain Zaatout -Biskra. http://archives.univ-

biskra.dz/bitstream/123456789/13497/1/Abdesslem_CHETTOUH_et_Saad_RIABI.pdf

17. Jameel, F.R., 2019. Investigation of biochemical blood parameters, characteristis for carcass, and mineral composition in chicken meat when feeding on coriander seed and rosemary leaves, Journal of advanced veterinary and animal research, 6, 1, 33-43, http://doi.org/10.5455/javar.2019.f309

18. Gadde, U., Kim, WH., Oh, S.T., Lillehoj, H.S., 2017. Alternatives to antibiotics for maximizing growth performance and feed efciency in poultry, Animal Health Research, 18, 26-

45, http://doi.org/10.1017/S1466252316000207

19. Giannenas, I., Florou-Paneri, P., Papazahariadou, M., Christaki, E., Botsoglou, N.A. Spais, A.B., 2003. Effect of dietary supplementation with oregano essential oil on performance of broilers after experimental infection with Eimeria tenella, Archive Tierernahrung, 57, 99-106, http://doi.org/10.1080/0003942031000107299

20. Gupta, T., Tiwari, D.P., Narayana, K.P., Mondal, B.C., Lata, M., 2021. Effect of dietary incorporation of aniseed (Pimpinella anisum) and ginger (Zingiber officinale) rhizome powder and their combination on haemato-biochemical parameters and carcass trait in broiler chicken, Journal of Animal Research, 11, 3, 547-553, http://doi.org/10.30954/2277940X.03.2021.27 
21. Hafeez, A., Sohail, M., Ahmad, A., Shah, M., Din, S., Khan, I., Shuiab, M., Nasrullah, Shahzada, W., Iqbal, M., Khan, R., 2020. Selected herbal plants showing enhanced growth performance, ileal digestibility, bone strength and blood metabolites in broilers, Journal of Applied Animal Research, 48, 1, 448-45, https://doi.org/10.1080/09712119.2020.1818569

22. Hashemi, SR., Zulkifli, I., Davoodi, H., Zunita, Z., Ebrahimi, M., 2012. Growth performance, intestinal microflora, plasma fatty acid profile in broiler chickens fed herbal plant (Euphorbia hirta) and mix of acidifiers, Animal Feed Science Technologie, 178, 167-74, https://doi.org/10.1016/j.anifeedsci.2012.09.006

23. Hemati, M., Fakhraei, J., Yaghobfar, A., Mansoori, Y.H., 2019. Effects of Hydroalcoholic Extract of Hogweed and Anise on Broiler Meat Quality, Immune Responses, and Intestinal Microflora and Morphology, Jundishapur journal of Natural Pharmaceutical Products, 15,1, 90870, http://doi.org/10.5812/jjnpp.90870

24. Hosseinzadeh, H., Alaw Qotbi, AA., Seidavi,A., Norris, D., Brown D., 2014. Effects of Different Levels of Coriander (Coriandrum sativum) Seed Powder and Extract on Serum Biochemical Parameters, Microbiota, and Immunity in Broiler Chicks, The Scientific World Journal, 3, 628979, https://doi.org/10.1155/2014/628979

25. Khubeiz, M. M., Shirif, A. M., 2020. Effect of coriander (Coriandrum sativum L.) seed powder as feed additives on performance and some blood parameters of broiler chickens, Open Veterinary Journal, 10, 2, 198-205, http://dx.doi.org/10.4314/ovj.v10i2.9

26. Kim,W.H., Lillehoj, H. S.. 2019. Immunity, immunomodulation, and antibiotic alternatives to maximize the genetic potential of poultry for growth and disease response, Animal Feed Science and Technology, 250, 41-50, https://doi.org/10.1016/j.anifeedsci.2018.09.016

27. Kirubakaran, A., Moorthy, M., Chitra, R., Prabakar, G., 2016. Influence of combinations of fenugreek, garlic, and black pepper powder on production traits of the broilers, Veterinary world, 7. 470-474, https://doi.org/10.14202/vetworld.2016.470-474

28. Kuralkar, P., Kuralkar, S.V., 2021. Role of herbal products in animal production, Journal of Ethnopharmacology, 278, 114246, https://doi.org/10.1016/j.jep.2021.114246

29. Lee, K.W., Everts, H., Kappert, H.J., Frehner, M., Losa, R., Benyen, A.C., 2003. Effects of dietary essential oil components on growth performance, digestive enzymes and lipid metabolism in female broiler chickens, British Poultry Science. 44, 450-457,

https://doi.org/10.1080/0007166031000085508

30. Lee, S.H., Lillehoj, H.S., Hong, Y.H., Jang, S.I., Lillehoj, E.P., lonescu, C., Mazuranok, L., Bravo, D., 2010. In vitro efects of plant and mushroom extracts on immunological function of chicken lymphocytes and macrophages. British Poultry Science. 51:213-221.

https://doi.org/10.1080/00071661003745844

31. Lillehoj, H., Liu, Y., Calsamiglia, S., Fernandez-Miyakawa, ME., Chi, F., Cravens, RL ., Oh, S., Gay, CG., 2018. Phytochemicals as antibiotic alternatives to promote growth and enhance host health, Veterinary Research, 49, 76, https://doi.org/10.1186/s13567-018-0562-6 
32. Mamoun, T., Mukhtar, M. A., Tabidi M. H., 2014. Effect of fenugreek seed powder on the performance, carcass characteristics and some blood serum attributes. Advance Research in Agriculture and Veterinary Science,1,1 6-11, www.aravs.org

33. Meradi, S., Messaï, A., Aouachria, M., Boussaada, T., 2020. Voies alimentaires d’amélioration des performances et de la qualité du poulet de chair: cas des épices en tant qu'additif alimentaire. Livestock Research for Rural Development. 32, 61, http://www.Irrd.org/Irrd32/4/merad32061.html

34. Mourot, J., 2009. Optimizing the nutritional and sensorial profile of pork. Book chapter: Improving the sensory and nutritional quality of fresh meat. Editors J. P. Kerry and D. Ledward, Woodhead Publishing in Food Science, Technology and Nutrition 166, 342355. ISBN: 9781845693435 . Publisher: Woodhead Publishing Ltd.

35. Srinivasa, U.M., Naidu, M.M., 2020. Chapter 6 - Fenugreek (Trigonella foenum-graecum L.) seed: promising source of nutraceutical. Edited by Atta-ur-Rahman, Studies in Natural Products Chemistry. 71. 141-184. ISBN 9780323910958, https://doi-org.sndl1.arn.dz/10.1016/B978-0-323-910958.00014-3

36. NRC, 2011. National Research Council, Guide for the Care and Use of Laboratory Animals: Eighth Edition. Washington, DC: The National Academies Press.

37. NRC., 1994. National Research Council. Nutrient requirements of domestic animals. Nutrient requirements of poultry, 9th revised Edition, National Academy Press. Washington, DC, USA. https://www.nap.edu/read/2114/chapter/1.

38. Oladokun, S., Adewole, D. I., 2020. In ovo delivery of bioactive substances: an alternative to the use of antibiotic growth promoters in poultry production-a review. Journal of Applied Poultry Research, 29, 3 , 744-763, https://doi.org/10.1016/j.japr.2020.06.002

39. Oueslati, H., Ghédira, A. K., 2015. Notes ethnobotanique et phytopharmacologique sur Trigonella foenum-graecum. Phytothérapie,13, 234-238, https://doi.org/10.1007/s10298-015-0934-2

40. Pathak, N.L., Kasture, S.B., Bhatt, N.M. and Rathod, J.D., 2011. Phytopharmacological properties of coriander sativum as a potential medicinal tree. Journal of Applied Pharmaceutical Science, 01, 04, 20-25. http://japsonline.com/admin/php/uploads/55_pdf.pdf

41. Paula,T., Margareta,O., Elena,U.,Mihaela,S., Iulia,V., Alexandru, V., 2020. Nutritional characterization of some natural plants used in poultry nutrition. Archiva Zootechnica, 23, 2, 58-

72, https://doi.org/10.2478/azibna-2020-0013

42. Petit, R. P., Sauvair, Y., Hillaire, D., 1995. Steroid saponins from Fenugreek seeds: Extraction purification and pharmacological investigation on feeding behavior and plasma cholesterol. Steroids, 60, 674-680, https://doi.org/10.1016/0039-128X(95)00090-D

43. Qureshi, S., Khan, H., Amin, U., Mir, M., Adil, S., Sofi ,A., 2020. Influence of cold stress and its remedial measures on jejunal Histomorhology of broiler chicken. The Pharma Innovation Journal, 9, 7, 225229. www.thepharmajournal.com 
44. Rahimi, S., Teymori Zadeh, Z., Torshizi, K., Omidbaigi, R. and Rokni, H., 2011. Effect of the three herbal

extracts on growth performance, immune system, blood factors and intestinal selected bacterial population in broiler chickens. Journal of Agricultural Science and Technology13, 527-539. http://jast.modares.ac.ir/article-23-5732-en.html

45. Rasouli, B., Movahhedkhah, S., Seidavi, A., Haq, Q.M.I., Kadim, I., Laudadio, V., Mazzei, D., Tufarelli, V., 2019. Vincenzo Tufarelli Effect of sage (Salvia officinalis L.) aqeous leaf extract on performance, blood constituents, immunity response and ileal microflora of broiler chickens, Agroforestry Systems, 94, 1179-1187. https://doi.org/10.1007/s10457-019-00401-8

46. Safaei, A., Rahanjam, S. M. Gharajanlu, M., 2013. Effect of Trigonella foenum-graecum on immune response and some blood parameters of broilers. Scholarly Journal of Agricultural Science, 3, 4, 117120, http:// www.scholarly-journals.com/SJAS

47. Saeid, J.M., AL-Nasry, A.S., 2010. Effect of Dietary Coriander Seeds Supplementation on Growth Performance Carcass Traits and Some Blood Parameters of Broiler Chickens. International Journal of Poultry Science, 9. https://doi.org/10.3923/ijps.2010.867.870

48. Samani, S.K., Ghorbani, M.R., Fayazi, J. Salari, S., 2020. The effect of different levels of Fenugreek (Trigonella foenum-graecum L.) powder and extract on performance, egg quality, blood parameters and immune responses of laying hens in second production cycle. Veterinary Research Forum, 11,1, 53-57, https://doi.org/10.30466/vrf.2019.80961.2072

49. Seidavi, A., Tavakoli, M., Slozhenkina, M., Gorlov, I., Hashem, NM., Asroosh, F., Taha, AE., Abd El-Hack, ME., Swelum, AA., 2021. The use of some plant-derived products as effective alternatives to antibiotic growth promoters in organic poultry production: a review. Environmental Science and Pollution Research, 28, 47856-47868, https://doi.org/10.1007/s11356-021-15460-7

50. Silva, F., Domeño, C., Domingues, F.C., 2020. Coriandrum sativum L.: Characterization, Biological Activities, and Applications. Chapter 35. Nuts and Seeds in Health and Disease Prevention, Second Edition, https://doi.org/10.1016/B978-0-12-818553-7.00035-8

51. Socaci, S. A., Fărcaş, AC., Tofană. M., 2020. Chapter 8, Functional ingredients derived from aromatic plants. Editor(s): Panagiota Florou-Paneri, Efterpi Christaki, llias Giannenas, Feed Additives, Academic Press, 2020, Pages 133-146, ISBN 9780128147009, https://doi.org/10.1016/B978-0-12814700-9.00008-X

52. Sugiharto, S., 2016. Role of nutraceuticals in gut health and growth performance of poultry, Journal of the Saudi Society of Agricultural Sciences,15,99-111.

http://dx.doi.org/10.1016/j.jssas.2014.06.001

53. Sunbul, J., Hamodi, Essa H., Al-Mashhadani, FK., Al-Mashhadani, A.H., 2010. Effect of Coriander Seed (Coriandrum sativum L.) as Diet Ingredient on Broilers Performance under High Ambient Temperature. International Journal of Poultry Science, 9, 10, 968-971, 2010, https://doi.org/10.3923/ijps.2010.968.971 
54. Wahab, F., Chand, N., Khan, RU., Ahmad, N., Parvez, U., Rehman, Z., Naz, S., 2019. Dietary Supplementation of Fenugreek (Trigonella foenum graecum) on the Egg Quality Characteristics of Rhode Island Red Spent Layers. Pakistan Journal of Zoology, 51, 10, 1793-1797, http://dx.doi.org/10.17582/journal.pjz/2019.51.5.1793.1797 